\title{
Muslim Woman Seeking Work: An English Case Study with a Dutch Comparison, of Discrimination and Achievement
}

\author{
Christopher Bagley ${ }^{1, *}$ and Mahmoud Abubaker ${ }^{2,3}$ \\ 1 Public Health Institute, Liverpool John Moores University, Liverpool L3ET, UK \\ 2 Leeds Business School, Leeds Beckett University, Leeds LS61AN, UK; mahmodypal@yahoo.co.uk \\ 3 Faculty of Management, Al-Aqsa University, 76888 Gaza, Palestine \\ * Correspondence: C.A.Bagley@ljmu.ac.uk
}

Academic Editor: Martin J. Bull

Received: 13 December 2016; Accepted: 10 February 2017; Published: 16 February 2017

\begin{abstract}
The measurement of discrimination in employment is a key variable in understanding dynamics in the nature of, and change in "race relations". Measuring such discrimination using 'situation' and 'correspondence' tests was influenced by John Rex's sociological analyses, and earlier work, begun in America, was continued in England in the 1960s, and further replicated in Europe and America in later decades. This literature is reviewed, and the methodologies of testing for employment discrimination are discussed. Recent work in Britain and the Netherlands is considered in detail in the light of changing social structures, and the rise of Islamophobia. Manchester, apparently the city manifesting the most discrimination in Britain, is considered for a special case study, with a focus on one individual, a Muslim woman seeking intermediate level accountancy employment. Her vita was matched with that of a manifestly indigenous, white Briton. Submitted vitas (to 1043 potential employers) indicated significant discrimination against the Muslim woman candidate. Results are discussed within the context of Manchester's micro-sociology, and Muslim women's employment progress in broader contexts. We conclude with the critical realist comment that the "hidden racism" of employment discrimination shows that modern societies continue, in several ways, to be institutionally racist, and the failure to reward legitimate aspirations of minorities may have the effect of pushing some ethnic minorities into a permanent precariat, with implications for social justice and social control in ways which may deny minority efforts to "integrate" in society's employment systems.
\end{abstract}

Keywords: racial discrimination; employment; United Kingdom; the Netherlands; black and ethnic minorities; women; Islam; alienation

\section{Introduction}

In the sociology of "race relations", discrimination in access to employment, housing and services has been of central consideration [1]. Discrimination on grounds of race, ethnicity and religion is deeply rooted in all human societies, and countering it must involve social, economic, political and psychological understanding and strategies [2]. The empirical study of racial discrimination using empirical testing through "situation" and "correspondence" testing [3] was pioneered in the U.S., and then developed in the United Kingdom in the 1960s. The degrees of discrimination identified have been paralleled by studies showing lower earnings and occupational achievements of ethnic minorities, when differing levels of age and educational achievements are taken into account [4].

Pioneering UK studies were keen to establish the degree of such discrimination through direct testing, establishing the extent to which social norms and practices failed to meet a Weberian "ideal 
type" of a rational social order in which all kinds of role access were governed by individual merit, rather than by stereotyped category. In Britain in the 1960s and 1970s, "situation testing" studies involved ethnic minority actors applying for jobs and housing, and it was clear that there was a marked degree of racial discrimination against black and ethnic minority applicants for jobs and housing, who were much less likely to receive offers than white actors or testers. Similar findings were obtained from "correspondence testing" in Britain and Europe, in which applicants submitted written applications for employment, or made telephone enquiries [5,6].

Understanding the reality of this discrimination in Britain led to the passage of the first Race Relations Act in 1965 which made such discrimination illegal, but with certain administrative concessions: thus, in the early versions of the legislation, small businesses with ten employees or less were exempted, as were small boarding houses of hotels with less than ten beds. Later versions of this Act (now subsumed under broader "Equality Legislation"), included no such concessions, and indeed prosecutions by government and individual litigation by workers has disappeared from the "equality" lens, as we discuss below in the case study of Britain's Equality and Human Rights Commission.

\section{Studying Discrimination: Methodological Issues, and Results of Earlier Studies}

"Racial discrimination" in a population has most frequently been inferred from attitudinal data which elicits agreement with statements about 'behavioural readiness' in response to questionnaires aimed at measuring prejudice concerning different groups [6,7]. While one would expect a person who declares the intention of discriminating against a particular kind of individual to actually discriminate when the occasion arose, there is no guarantee that he or she would actually do so. An alternative (although logistically difficult) strategy is to have individuals (e.g., actors) apply for advertised jobs, vacancies or services. This design was employed in Britain by Daniel [8] who showed that in about half of the situations (for employment or housing vacancy) an African-Caribbean applicant was discriminated against, compared with the acceptance of the white applicant.

In Jowell and Prescott-Clarke's [9] "correspondence test" study, a native-born white Briton, and migrants from the West Indies, Asia, Australia and Cyprus submitted letters of application for employment, stressing both their excellent qualifications and experience, and their migrant or ethnic status: 'white' immigrants were called for interview in 74 percent of cases, compared with 52 percent of Asians and West Indians. While this study indicated significant discrimination against visible minorities, it did nevertheless show that about half of the British employers approached were, initially at least, non-discriminatory. However, the authors speculated that recent publicity surrounding the Race Relations Act could have influenced initial responses, and that the actual interview process might include implicit or explicit biases whose subtleties of rejection would be hard for any legislation (or applicant) to detect. At least there had been some advance from the frequently seen public advertisements of the early 1960s prior to the 1965 Race Relations Act, the advertisements boldly declaring: "Accommodation Available: No Blacks, No Dogs, No Irish" [10,11]. In 1974, despite legislation, employers were still discriminating against black and ethnic minority applications [12].

Pager and Shepherd [13] have surveyed mainly American studies of the measurement of racial discrimination, which they report is still "subtle but strong" despite the gains following the Civil Rights era up to the 1970s, and concluded that such discrimination remained "a major problem in the USA". The sociological evidence on discrimination which they collected came from three sources: (1) studies of the agents of discrimination, using qualitative or concealed methodologies; (2) statistical analyses of income and employment profiles of minorities, controlling for educational achievements, to judge whether systematic discrimination might have taken place; (3) quasi-experimental studies using "situation testing" (e.g., actors, playing the role of minority applicants; and/or applying for advertised jobs using "correspondence testing" by submitting job applications in which the ethnicity of the applicant, e.g., European-American, or African-American) was manifest. Pager and Western in 2012 [14] using both correspondence and situation testing, further showed that discrimination against African-Americans remained marked. 


\section{Recent Studies of Racial and Ethnic Discrimination in Britain}

Wrench and Modood [4] identified a move away from government concern with ethnic discrimination in the workplace by 2000, with the Commission for Racial Equality leaving responsibility for litigation under the Race Relations Act to individuals, if they were able to obtain trade union support. They suggested that governments were now relying on the "natural benevolence" of employers, and an innate sense of British fair play to prevent racial discrimination occurring [4]. Successful litigation using the Race Relations Acts was now extremely rare. However, the failure of the "natural benevolence" argument is amply demonstrated by research studies, reviewed below.

Analysing data from the 2001 British Census, Khaltab [15] showed that combinations of being Muslim, black, and female were particularly likely to result in employment status and wages which reflected racial discrimination. On such 'intersectionality' (focussing, for example, on efforts to raise the consciousness and opportunity avenues of young Muslim women), Rashid [16] offers an interesting account of Muslim women addressing the government's "extremist" agenda (discussed in more detail below). Our own case study of intersectionality ('Muslim woman seeking work') could form the basis of a consciousness and opportunity-raising enterprise ${ }^{1}$.

Reviewing time trends in relation to economic cycles, Li and Heath [17] found that Black and Ethnic Minority (BEM) men's unemployment levels were significantly higher than those of British-born whites in the period 1972 to 2005, results which held even after effects of previous educational qualifications were taken into account.

Heath and Cheung [18] offer a useful review of the employment situation, including experience of racial discrimination experienced by Black and Ethnic Minorities (BEM) adults in Britain using a variety of data sources, and try and partial out the degree to which employment profiles reflect either educational profiles, and discrimination by employers. Their results showed that Pakistani, Bangladeshi, Black Caribbean and African men "...continue to experience higher unemployment rates, greater concentration in routine and semi-routine work and lower hourly earnings than do members of the comparison group of British and other (foreign-born) whites." These findings imply widespread racial discrimination, rather than the age or educational levels of BEM individuals applying for jobs. Similar results were obtained for BEM women. The situation for men and women of Pakistani and Bangladeshi origin was, amongst the BEM group, particularly disadvantaged. Their continued employment in low-skilled work, and their frequent spells of long unemployment, could not be explained by age, educational attainments, or recency of immigration. There was a tendency for older Pakistani and Bangladeshi workers to seek to adopt "the sick role" as an alternative to the fruitless research for adequate work. The situation had improved only marginally for the adult children of migrants. The only ethnic groups not severely disadvantaged economically were Indian and Chinese. BEM workers tended to seek employment in governmental and health service sectors, probably because of government monitoring policies which highlighted discrimination in public institutions; but also because low pay in these sectors made these posts relatively unattractive to whites.

For women "ethnic penalties" (lack of hiring, or employment on lower pay than whites) was, according to Heath and Cheung [18], "marked". Using various data sources to support these arguments, the authors found that these "ethnic penalties" pertained in manufacturing, distribution, private transport companies, and banking: "Getting a good education is not, on its own, enough." The authors observe that the Race Relations (Amendment) Act of 2000, which shifted the focus from legal interventions on discrimination by private companies, to public institutions. They advocated the addition of systematic monitoring of racial discrimination by the private sector (e.g., through the

1 For example, the Manchester Muslim Engineers Association was formed some years ago, its purpose being to network information among members on the best qualifications to aim for, the best colleges and courses, the employers least likely to discriminate, current salaries, notice of upcoming vacancies, and strategies to use when interviewed. This group also meets socially, for purposes of mutual support. 
Equality and Human Rights Commission, and the Confederation for British Industries). This has not occurred.

Brynin and Guveli [19] analysed the British Labour Force survey data for 1993-1997, contrasting this analysis with the data for 2004-2008, looking for changes in patterns of ethnic disadvantage, and whether income disadvantage for BEM groups was due to failure to enter certain occupational sectors, or whether once recruited, pay differentials were imposed on BEM individuals. The former appeared to be the case, since the data indicated patterns of employment segregation reflecting entry-level discrimination in denial of employment. Moreover, the picture in the later years (to 2008) was as bleak as in the earlier period. Looking at income differentials in more recent data, Brynin and Longhi [20] show that BEM workers were the most disadvantaged of any group of British workers, more than half not achieving the Rowntree Foundation's "minimum living wage" level.

Following Clark and Drinkwater's [21] account of the complex of interacting factors which diminish wage levels and status of employment in ethnic minorities, Dyke and James [22] studied, using telephone interviews, 634 English women of Pakistani or Bangladeshi origin: all were Muslim. The motivation for this research was the finding from literature surveyed that South Asian, Muslim women were the most discriminated against group in access to employment in the UK. While 57 percent of the women contacted said they would like to work outside of the home (and indeed some were already doing so), 49 percent could not seek work at that time because of child care responsibilities. The researchers did not attempt to estimate the degree of rejection which these Muslim women were experiencing in the search for employment, but observed that many had become inhibited in seeking work because of the fear of discrimination. The authors of this study advocated the setting up of special placement agencies in British cities, which would liaise with employers, establishing potential avenues of work, and of training opportunities for Muslim women. So far as we can establish, such agencies have not been set up.

The most comprehensive study of racial discrimination in Britain using "correspondence testing" in job applications comes from a report by Wood et al. [23] who examined the rejection of curriculum vitae which implied an ethnic minority origin, compared with the acceptance of a similar $\mathrm{CV}$ when it was clear that the applicant was "an indigenous, white". Three similar CVs (varying only by ethnicity) were submitted for posts advertised in seven major British cities, in nine categories of occupation. One CV was always on behalf of the "white British" candidate; the further two CVs included, randomly, CVs contrasted by presumed ethnicity (African-Caribbean; Chinese; Indian; Pakistani/Bangladeshi). Pre-testing showed that for example, the "average" white adult was able to identify "Andrew Clarke" as white, and "Eroll Griffiths" as black. Religion of candidate was not made explicit in the CVs. All candidates claimed to be born and educated in the UK.

Overall, 2961 "applications" were made for 987 advertised vacancies (84\% on a 'job-search' web site, the remainder in newspaper ads), in 2008-2009, a period of recession in the British economy. "Success" was judged to be if an employer responded to an applicant with a request for an interview, or further details. Overall, only 16 percent (155 out of 987 advertised posts) responded to any of the applicants. "Net discrimination" was the negative difference between a "white" applicant being contacted, versus a "non-white" or "minority ethnicity" candidate being contacted for interview or further particulars.

The net difference - the index of discrimination—of 29 percent across all of the seven cities, was highly significant, in statistical terms. However, degrees of discrimination varied between the cities, being lowest in Bradford and Leeds (at 20\% net discrimination) and highest in Manchester (at 42\%). The authors of the report do not calculate significant differences between individual cities, but their data allow this to be done: when Manchester is compared against the other six cities (Bristol was the next highest in net discrimination, at $27 \%$ ) the difference is highly significant: that is, in statistical terms, Manchester employers were significantly more discriminating than employers in any other city. No factors in the test situations could be adduced to explain these differences, but we have to 
entertain the hypothesis that factors within Manchester's social system make life more difficult for ethnic minorities.

Other findings emerging from this study were that women, overall, were slightly less discriminated against than men; employers advertising higher status jobs (requiring professional qualifications) were more accepting of ethnic minority candidates; employers posting jobs on a web-site were less discriminating than those advertising in the local press; and public sector employers were more accepting of minority candidates. Nevertheless, even when combining these "favourable" factors, employers' discrimination in favour of white candidates remained statistically significant. Overall, the "ethnic minority" candidates had to submit around twice as many CVs as their "white" counterpart, in order to gain an interview.

A methodological point must be made. No comment is made by Wood et al. [23] —or by any previous researchers that we can locate- on the biasing effect of submitting two very similar CVs differing only by the ethnic name of the applicant. Would not an employer who carefully studies the documentation submitted think it odd that two candidates were exactly similar in qualifications and experience? If the researchers try and avoid "suspicious coincidences" by varying significant details in the vitae, then would not the experiment be invalidated; or would the suspicious employer reject both strangely similar candidates? We have tried to avoid this problem in the "correspondence" study reported below by submitting exactly similar vitae (apart from the ethnic name) not to the same employer, but to two sets of potential employers who advertised vacancies which with sufficient numbers, should allow for minor differences in the posts applied for to randomise.

Martin, Heath and Boswell [24] draw together the literature on disadvantages in the labour market which being both and ethnic and a religious minority entail, using a variety of data sources: "The results demonstrate a strong 'Muslim penalty' for women from different ethnic groups. There were also ethnic penalties which persisted despite allowing for religion, in particular for Black Caribbean and Black African women." Thus, for some women, there was a triple disadvantage: being female, being non-white (of Pakistani, Bangladeshi or African origin), and being overtly Muslim. Women who had "obviously" been born in Britain experienced slightly less discrimination in employment.

In Britain, studies show that BEM workers who obtain high level professional and university qualifications actually encounter more discrimination, as being 'suspiciously overqualified' [25]. Setting up a small business is an alternative for ethnic minorities when faced with discrimination in employment: but small manufacturers are likely to meet discrimination in their supply chain and sales outlets [26]. Small business development by British Pakistanis and Bangladeshis are moderately successful in reducing "the ethnic penalty", but fail to lift African-Caribbeans out of the ethnic bands of poverty [27].

Research from the House of Commons Women's and Equalities Committee [28] established that unemployment rates in Muslims in Britain were twice as high as those for any other group: 65 percent of Muslim women who wished to work, remained unemployed. Research for the Committee indicated that some "situation testing" had shown that hijab-wearing women were particularly likely to experience discrimination in job-seeking. Employers were four times as likely to ask Muslim women candidates about 'family obligations' which, inferentially, might interfere with their commitment to employment. Of the employers interviewed, 25 per cent said that they would be "hesitant" about considering a Muslim woman for employment. The Parliamentary Committee found some evidence that Muslim women were removing hijabs (head covering), and adopting Anglo first and/or second names in order to obtain employment. Parallel to this report, the Trades Union Council [29]) found that Black and Ethnic Minority women were a third more likely to be unemployed that were their male counterparts. Once employed, they earned less for the same work than did male counterparts, and were more often required to accept fewer hours of employment. 


\section{The Role of the Equality and Human Rights Commission in Britain in Preventing Racial, Ethnic and Religious Discrimination}

This publicly-funded organisation grew in part from the Race Relations Board (RRB), which was set up to monitor (and improve) the workings of the Race Relations Act of 1965 (Britain's first legislation in this area). The RRB's first report presented to the Home Secretary indicated that "the Board" constituted of nine part-time members, with some secretarial support, and they were unable to initiate prosecutions under the Act. Their role was simply that of monitoring and advocacy. The RRB became the Commission for Racial Equality (CRE) in 1976, following the passage of a somewhat strengthened Race Relations Act of that year. This "non-departmental public body" had a stronger role and was better funded that the RRB, but in 2004 its function regarding "race" was ended, when it was merged with a newly created Equality and Human Rights Commission (EHRC). In fact, the CRE's extensive library on "race and ethnicity" was donated to a university, and many of its specialist staff left or were dispersed into other roles.

The EHRC simultaneously absorbed the Equal Opportunities Commission (concerned with sexual discrimination) and the Disability Rights Commission. Initially it had a much larger budget than the CRE, but also much broader mandate. This involved being responsible for monitoring, advice and policy on lack of equality (because of, inter alia, discrimination) in the fields of: "Age, disability, gender, gender realignment, sexual orientation, and race." [30]. Religion was not included in this remit unless (as in the case of Jews and Sikhs) religious beliefs coincided with a "racial" (sic) category. This meant that Muslims, who can be of any ethnicity, were not directly covered by the EHRC's concerns with equality and discrimination. ${ }^{2}$

Action on discrimination is not initiated by the EHRC: it is left to individuals, to bring their case to an "Employment Tribunal", which has a quasi-legal, mediating role in cases of alleged discrimination or other unfair practices-but it can order payment of significant financial redress for successful claimants. However, without Trade Union support, Black and Ethnic Minority individuals rarely seem to bring claims of discrimination to these Tribunals. We have been unable to obtain any publicly available information on the nature of cases brought, since the Tribunals almost always seek to achieve compromise between the contesting parties, and these kinds of decisions are de lege, unavailable for public scrutiny. The most recently available comprehensive report of the UK Employment Tribunals [32] indicated that only 163 of the 12,781 cases presented, alleged "racial discrimination".

No information is given on the nature of these cases, though for all cases $43 \%$ were withdrawn; "conciliation" was obtained between the parties in 37\%; and up to $20 \%$ of complainants "did not attend" the Tribunal. A complainant has to pay a fee of $£ 250$ to file a complaint, and a further $£ 950$ to the Tribunal if the case is proceeded with. The lone worker, believing that he or she has been the victim of racial, ethnic or religious discrimination has many difficult hurdles to overcome in seeking redress, and it is not surprising that so few seek support from an Employment Tribunal. The worker who feels that he or she has been discriminated against will rarely have access to evidence which might prove that rejection was on grounds of race or ethnicity, rather than on lack of merit, since they are unlikely to have access to information on the internal decisions made by the company in question. A brief report from the Tribunals office [33] reported a 38\% fall in claims since fees were introduced. Most successful awards were in the field of sexual discrimination in hiring, pay, and dismissal: race and ethnicity were not mentioned.

The EHRC issued a major report in 2015 [34] with the perhaps ironic title Is Britain Fairer? The answer seemed to be: almost certainly not. The EHRC's changing vision was meant to focus on

2 The dynamic energy of the Equal Opportunities Commission seemed to have been lost when it was absorbed within the body with the broader remit. Initiatives such as the valuable, sponsored research of Bradley and Healy [31] on ethnicity and gender at work - giving qualitative accounts of struggle against discrimination — have not been paralleled or replicated in the larger EHRC. 
the following tasks: (1) Improve the evidence base for judging how fair society is; (2) Raise standards and close attainment gaps in education; (3) Encourage fair recruitment, development and reward in employment; (4) Support improved living conditions in cohesive societies; (5) Improve access to mental health services and support for those experiencing poor mental health; (6) Prevent abuse, neglect and ill-treatment in care and detention; (7) Tackle targeted harassment and abuse of people who share particular protected characteristics.

In all of these areas, except the first, Britain has, in our estimation, failed. There is however a sufficiently developed body of statistical data through which commentators can accurately describe the manifest unfairness of British society in general, and of its racist nature in employment practices in particular, as evidenced for example in the series of monographs issued by the Rowntree Foundation [20,35]. ${ }^{3}$ These data show that substantial numbers of BEM individuals earn less than Rowntree's estimate of "a living wage"; these levels of low pay and relative poverty remain largely unchanged during the present century; and although significantly fewer white Britons are overtly racist, levels of discrimination in access to employment have remained substantial, and largely unchanged ${ }^{4}$.

Following the election of a coalition (Conservative-Liberal) government in 2010, the EHRC's annual budget was cut from $£ 70$ million (in 2009-2010) to $£ 12.1$ million (in 2014-2015), at the time that its remit was becoming ever wider [37]. Several hundred of EHRC's employees became redundant or left over five years, and there were no signs that the trend of reduced funding would not continue. In its annual report for 2016, EHRC reported a focus on "hate crimes" against three groups: the disabled, LGBT people, and Black and Ethnic Minority groups. Racial discrimination in the workplace was very far from the horizons of this diminishing group. Any connection which the EHRC had with black and ethnic minority communities seemed now to have been lost [30]. The EHRC had not been able to grasp the growing problem of Islamophobia, despite (or because of) its widespread and expanding nature [38-40].

\section{Racial Discrimination in the Netherlands: Historical Trends}

Bagley in 1973 [41] attempted to replicate the English research of Daniel [8] using real individuals (actors, with various ethnic backgrounds) in applying for qualified accountants' advertised positions, in London and Amsterdam, as well as in applying for tenancy of apartments. In each setting, the applicants were indigenous whites; West Indian (Jamaican, or Surinamese); and non-British or non-Dutch white-European respectively. In the 60 'situation tests' of advertised employment, the Dutch West Indian was discriminated against in 30 percent of his applications; but the English West Indian was rejected in 75 percent of cases, in which the white tester was offered an interview. Similar levels of discrimination pertained in applications for accommodation. Bagley [8] argued from his results that individuals (e.g., Surinamers) who fitted into the Dutch 'plural society' were much less likely to be discriminated against than were 'foreigners', strangers to what, at that time, was a rigid system of bloc separation. Since that time, the Dutch plural society has changed profoundly, and the traditional blocs and pillars no longer exist [42,43].

These changes in Dutch social structure have resulted, paradoxically, in an increase in hostility towards ethnic minorities such as settlers from the former Dutch colony of Suriname. Today, in the Netherlands as in other parts of Europe, the most stigmatised minorities are Muslims [39,44]. In Britain, Muslim minorities are mostly the descendants of settlers from the Indian Sub-Continent, with substantial numbers also from East and West Africa, the Middle East, and Malaysia. According to

3 Policy Exchange, an independent pressure group, also gathers together current data on income and employment disadvantage experienced by UK ethnic minorities: www.policyexchange.org.uk.

4 It may be that employment gatekeepers are not amongst those whose opinions have become more liberal; or else that facile liberalism hides implicit prejudice. It is for this reason that Quillan [36] in a review of the American evidence suggest the "implicit prejudice measures" should be operationalised in understanding the continuation of racial discrimination in employment. 
the 2011 National Census, some five percent of the British population are Muslims, most being in the younger age groups, either in education or in the early stages of working careers. In the Netherlands, Muslim minorities (some four percent of the total population) are like their co-religionists in Britain, victims of Islamophobia. Dutch Muslims are descended mainly from settlers from Turkey, Morocco, and other North African countries, and have always stood outside of the verzuiling system [42]. Indeed, Bovenkerk et al. [45] in comparing methodologies for studying racial discrimination in Dutch, French, Swiss and Austrian cultures, found that Dutch Moroccans (especially males) were subject to considerable degrees of rejection (in 56\% of employment applications), compared with other ethnic minority groups.

Andriessen and colleagues have examined more recent levels of discrimination surrounding perceived Muslim minorities in Randstad Holland ${ }^{5}$, by submitting resumes for advertised job vacancies, indicating that the applicant was either of "purely" Dutch origin, or had Islamic antecedents. This recent, extensive Dutch research by Andriessen et al. [46-49], and Nievers and Andriessen [50] has shown that racial discrimination in the Netherlands is actually increasing, in the age of Islamophobia. A consideration of this Dutch research was the stimulus for the present researchers to replicate to some extent, these modern Dutch studies, in order to gain an up-to-date, comparative perspective on aspects of employment discrimination in England and the Netherlands. ${ }^{6}$

In the work of Andriessen and her colleagues over several years, various methodologies were employed, including the use of actors applying for advertised jobs, and the submission of CVs identical except for the name (and implied ethnicity) of the candidate. Either the 'twin' CVs were virtually similar, or the minority candidate had enhanced qualifications and experience. Several thousand 'situation tests' were made, using varying methodologies. These tests showed that the well-qualified Dutch, "white", candidate was successful in gaining access to an interview in up to a half of their applications, while the Moroccan or Turkish "Muslim" candidate was successful in a little under a fifth of applications: these results give a net figure for discrimination of around 20 percent, which is approximately the same as that obtained in the English study by Wood et al. in fieldwork in 2008 [23]. These results showed, then, that there remains significant potential job discrimination against ethnic and religious minorities in the Netherlands, which seemed greater than that in our earlier work in Amsterdam and The Hague [41], although differences in methodology make accurate comparisons difficult. We would hypothesise, nevertheless, that the levels of employment discrimination for minorities may have been worsening with the collapse of the Dutch plural society system [42].

\section{The Manchester Case Study}

The whole assemblage of buildings is commonly called Manchester, and contains about 400,000 inhabitants, rather more than less. The town is peculiarly built, so that a person may live in it for years...without coming into contact with a working people's quarter ([51], p. 85).

While the back-to-back housing sketched by Engels has now been demolished, some zones of deprivation Engels identified, in Salford and Hulme, Pendleton, Chorlton, Ardwick, Cheetham Hill and Broughton remain today, despite massive "slum clearance" and movement of the former tenants to large areas of council-housing in Wythenshawe, and Handforth. Manchester was the city manifesting the highest levels of "racial discrimination" in the correspondence-testing of employment applications administered by Wood et al. in 2008 [23]. Why is not clear. ${ }^{7}$ Greater Manchester's population is now 2.68 million, of whom about 8.6 percent are Muslims, mainly Britons of Asian and Middle Eastern

5 The urban, administrative and industrial heartland of the Netherlands, including Amsterdam, The Hague, Rotterdam and Utrecht.

6 We are currently replicating the Manchester "correspondence testing" used in the present study, in Amsterdam.

7 Bunglawala in 2008 [52] in comparing ethnic underemployment in London, Leicester and Manchester observed that there was "significant" under-employment in Muslim women in Manchester. She advocated various Job Centre initiatives to counter this underemployment. Results, if any, of these initiatives are not available. 
origin. Manchester has 62 listed Mosques. Islam in Manchester compared to, say Amsterdam ${ }^{8}$, is confident and outgoing and dominates much of the restaurant trade in the university districts.

The study reported here was planned in one of Manchester's finer suburbs, Didsbury (discretely separated from the white working class zones identified by Engels), where in the local mosque attended by the researchers, collaboration with a Muslim woman who was planning to return to work after 'completing' her family, provided the essential "subject" whose curriculum vitae formed the basis for a "correspondence test" in applying for mid-level accounting vacancies. Our "subject", Aminah's ("Ami") history is this: she was born in Manchester, to immigrant, Pakistani parents, and attended an all-girls' local authority high school with a high proportion of Muslim pupils, and achieved good General Certificate results. Leaving school with two good Advanced-level passes, she obtained a junior administrative position with a Housing Association, and took courses at Manchester College part-time, specializing in accountancy.

Towards the latter part of her 3-year employment, she concentrated on accountancy tasks. Ami married at 20, her husband working in his father's travel agency (specialising in Hajj and Umra tours, and travel to Middle Eastern countries, and Pakistan). She left employment in the fourth month of her first pregnancy, and in the following eight years had three children. ${ }^{9}$ In the letter accompanying her vita she wrote: Now that my three children are attending school, and my mother-in-law who has recently retired, can take on child care arrangements, I am seeking to return to full time employment. I have, since leaving employment with [the Housing Association] worked occasionally in my husband's business, handling the accounts of a busy travel agent, including client accounts, payment to airlines, tax calculation, and liaising with HMRC. The reason for this (accurate) statement was to reassure potential employers that Ami's family demands would be unlikely to conflict with the demands of work. The e-mail address she gave in her applications was (in paraphrase, to conceal her identity): aminah.husain.muhammad@ so that employers would clearly know her religious and ethnic background. The second CV for "Emily Woodward" (a fictitious name) was identical in every respect to Ami's vita, including birth date, school attended, school and career examination successes and grades obtained, accounting qualifications, and occupational history.

Ami's qualifications in accountancy (including those resulting from home study using on-line and correspondence instruction with commercial education providers) achieved NVQ (National Vocational Qualifications) Level 4, the equivalent to a Foundation Degree level. She was successful in the first part of the Advanced Diploma in Accounting offered by the Association of Accounting Technicians, with whom Ami achieved professional registration. This British qualification is recognized by bodies such as the Institute of Chartered Accounts, and achievement of levels 5 and 6 allows the individual, after successful professional experience and submission of professional case studies, to full recognition as a chartered accountant. Level 4, achieved by Ami during her part-time study while at home with children, enabled her to claim skills in final accounts preparation for sole traders and partnerships, management accounting and costing, calculation and payment of direct and indirect tax liabilities, and facility in computer software in preparing and balancing accounts, and managing employee expenses and payrolls.

8 The proportion of Muslims in the Amsterdam population is around 14\%, nearly twice that of the proportion in Manchester. There are "only" 29 listed Mosques in Amsterdam, and for the visiting Muslim they are often difficult to find, and poorly signed. Islam in Amsterdam seems to be trying to stay "under the radar" in a society which increasingly requires conformity to some kind of secular civic standard which has emerged from the post-pillarization process [53]. This has coincided with a rise in Dutch Islamophobia [44].

9 Popular stereotype claims that Muslim woman are suppressed and subordinated to their husbands, and rarely wish to seek work outside of the home unless their husbands wish it. Our study of women graduates employed in the telecommunications industry in Palestine and Jordan suggests that this is not true. Women are powerful "family managers", matriarchs if you will, and men's role is external to the family, as "breadwinners". An unemployed man is not expected to stay at home during the day. Women who enter the external labour force are able, through the deference to women afforded by Islam, to command Work Life Balance benefits that their Western sisters would envy $[54,55]$. 
In submitting pairs of $\mathrm{CVs}$, the researchers faced the dilemma, which previous researchers using correspondence testing have not mentioned: submitting two identical CVs (apart from differing ethnic names) might well alert potential employers to the oddity of this coincidence, making it more likely that both CVs would be ignored. Making the CVs unalike in some way to avoid this possibility would surely introduce uncontrolled variables into the experiment. To avoid this problem, we submitted the CVs singly, to employers who gave details of vacancies in the Manchester area on a web-based advertising system: that is, only one $\mathrm{CV}$ was submitted to each employer.

The employers approached were advertising intermediate level accounting positions, with tasks which Ami was certain she could perform, offering annual salaries of about $£ 19 \mathrm{~K}$ p.a. (in 2015 to 2016). ${ }^{10}$ We continued submitting CVs until we had sufficient employers in the two groups who were similar (in modal terms) in salary offered, size and function of the organisation, type of employment, specific job requirements, and skills required: thus, we submitted (on Ami's behalf) the ethnic minority $\mathrm{CV}$ to 516 employers, and the CV of the "white" candidate (Emily) to 527 advertisements, ending the experiment when the two sets of employers appeared to be identical in their overall characteristics.

The final results can be simply stated, and confirm the image of Manchester as a city whose outgoing Muslim community is not, by some employers at least, well accepted: Ami received a positive phone call or e-mail for 151 of her 516 applications (29.23\%), compared with Emily's success rate of 306 of her 527 applications (58.06\%), a net difference of 28.8 per cent. Chi-squared analysis with one degree of freedom yields a value of 87.85 , the probability of a chance result being virtually zero. ${ }^{11}$

\section{Conclusions: The Hidden Crime of Racial Discrimination}

Racial discrimination in employment in Britain and the Netherlands is widespread, and has barely diminished in the past fifty years, although it takes new forms in targeting religious minorities, in addition to people of colour. 'Visibly Muslim' women are particularly likely to be targets of discrimination, both in Britain and the Netherlands. Yet such discrimination is a hidden crime, largely missing from public understanding and debate: it is "absent", as critical realists would term it [56,57]. Nevertheless, employment discrimination is a deeply embedded part of modern society in North America and Europe. Insofar as racism helps to mould a permanent underclass, it creates what Standing [58] calls a "dangerous" underclass, one liable at points of tension to violently rebel [59].

In terms of alienation theory, when legitimate aspirations are blocked, individuals may blame themselves, and retreat into ritual or escapist modes; or they may rebel, in both legal and illegal modes [43]. We hypothesize that the alienation imposed by racist social structure is more dangerous for society, than is the alleged radicalisation of youth by some elements of Islam. Countering this radicalisation, Muslim educators spell out the material and spiritual "success" that is inherent in Islam [60,61]. Ami's success in our case study is not just the material reward for a woman who carries her Muslim heritage proudly; it is her spiritual success in following the 'straight path' of Islam.

The British establishment attempts to uphold a set of values, which it imposes on schools and colleges through a system of education and social control, by means of its "prevent" strategy, authorised and funded by the regulations of the Counter Terrorism and Security Act of 2015, nominating as "non-violent" extremists (with severe civil penalties) those who are advocates of peaceful jihad [62]. Parallel issues occur in the Netherlands, as for example when the moderate Muslim, Tariq Ramadan [63] was deprived of his university position, and forced to leave Rotterdam for maintaining that Islam could become a separate pillar of Dutch society [64].

10 There is an ethical issue here of course, in that some potential employers will be momentarily deceived in considering false CVs. An ethics committee agreed with us (as had ethics committees for previous researchers) that this brief confabulation was justified, provided employers offering an interview were advised immediately of the applicant's decision.

11 On a positive note, hijab-wearing Ami accepted one of the positions offered, and after a year was promoted to a post earning $£ 23 \mathrm{~K}$ p.a., with added responsibility as the firm's accountant. 
The British establishment urges ethnic and religious minorities in Britain to "integrate", effectively meaning that they should assimilate, giving up public manifestation of different styles and manifestations of dress, religion, language, etc. Morally implicit in this assimilationist position is a social contract in which the minority group, as a reward for conformity, would be offered tolerance and acceptance [43]. The evidence we have reviewed, and our own empirical study of Manchester shows how problematic fulfilling that promised social contract may be. However, much minorities conform, become educated, fill employment niches, apply again and again for jobs easily offered to indigenous whites, they continue to be discriminated against, with long-term consequences for income and welfare. Why should marginalised Muslim youth conform to general values, in what for them is, apparently in many of its institutions, a racist society? This final question is a crucial one, to which we have no answer.

Funding: This research was not externally funded.

Author Contributions: The research was conceptualized by the first author (CB), who wrote the paper. The second author $(\mathrm{MAB})$ made substantial contributions in jointly undertaking the research and literature review, analyzing the findings, and critiquing drafts of the paper.

Conflicts of Interest: The authors declare no conflict of interest.

\section{References}

1. Rex, John. Race Relations in Sociological Theory. London: Weidenfeld and Nicholson, 1970.

2. Banton, Michael. International Action against Racial Discrimination. London: Oxford University Press, 1996.

3. Riach, Peter A., and Judith Rich. "Field experiments of discrimination in the market place." The Economic Journal 112 (2002): 480-518. [CrossRef]

4. Wrench, John, and Tariq Modood. The Effectiveness of Employment Equality Policies in Relation to Immigrants and Ethnic Minorities in the UK. Geneva: International Labor Office, 2000.

5. Bovenkerk, Frank. Testing Discrimination in Natural Experiments. A Manual for International Comparative Research on Discrimination on the Grounds of 'Race' and Ethnic Origin. Geneva: International Labor Office, 1992.

6. Bagley, Christopher, and Gajendra K. Verma. Racial Prejudice, the Individual and Society. Aldershot: Ashgate, 1979.

7. Bagley, Christopher, Gajendra K. Verma, Kanka Mallick, and Loretta Young. Personality, Self-Esteem and Prejudice. Aldershot: Ashgate, 1979.

8. Daniel, William Wentworth. Racial Discrimination in England. London: Penguin, 1968.

9. Jowell, Roger, and Patricia Prescott-Clarke. "Racial discrimination and white collar workers in Britain." Race and Class 11 (1970): 398-417. [CrossRef]

10. Lydon, John, Keith Zimmerman, and Kent Zimmerman. Rotten: No Irish, No Blacks, No Dogs. London: Hodder and Stoughton, 1994.

11. Nwanokwu, Gus Michael. Black Shamrocks: Accommodation Available—No Blacks, No Dogs, No Irish. Privately printed autobiography, distributed by Amazon Marketing, UK, 2016.

12. Ballard, Roger E. H., and Bronwen M. Holden. "The employment of coloured graduates in Britain." New Community 4 (1975): 325-36. [CrossRef]

13. Pager, Devah, and Hana Shepherd. "The sociology of discrimination in employment, housing, credit and consumer markets." Annual Review of Sociology 34 (2008): 181-200. [CrossRef] [PubMed]

14. Pager, Devah, and Bruce Western. "Identifying discrimination at work: The use of field experiments." Journal of Social Issues 68 (2012): 221-37. [CrossRef] [PubMed]

15. Khattab, Nabil. "Winners' and 'losers': The importance of education, ethnicity and gender on Muslims in the British labour market." Work, Employment and Society 26 (2012): 556-73. [CrossRef]

16. Rashid, Naaz. "Just a girl: Thinking intersectionally about the Muslim girl, and writing against culture." Young (Sage Open) 24 (2016): 255-69. [CrossRef]

17. Li, Yaojun, and Anthony Heath. "Minority ethnic men in British labour market (1972-2005)." International Journal of Sociology and Social Policy 28 (2008): 231-44. [CrossRef]

18. Heath, Anthony, and Sin Yi Cheung. Ethnic Penalties in the Labour Market: Employers and Discrimination. Research Report No. 341. London: Department of Work and Pensions, 2006. 
19. Brynin, Malcolm, and Ayse Güveli. "Understanding the ethnic pay gap in Britain." Work, Employment and Society 26 (2012): 574-87. [CrossRef]

20. Brynin, Malcolm, and Simonetta Longhi. The Effect of Occupation on Poverty among Ethnic Minority Groups. York: The Joseph Rowntree Foundation, 2015.

21. Clark, Ken, and Stephen Drinkwater. Ethnic Minorities in the Labour Market: Dynamics and Diversity. Bristol: The Policy Press, 2007.

22. Dyke, Anya Hart, and Lucy James. Immigrant, Muslim, Female: Triple Paralysis? London: The Quillam Foundation, 2009.

23. Wood, Martin, Jon Hales, Susan Purdon, Tanja Sejersen, and Oliver Hayllar. A Test of Racial Discrimination in Recruitment Practices in British Cities. London: Department for Work and Pensions, Government of the United Kingdom, 2009.

24. Martin, Jean, Anthony Heath, and Karin Bosveld. "Is Ethnicity or Religion More Important in Explaining Inequalities in the Labour Market?" Working Papers in Sociology 2010-2, University of Oxford, Oxford, UK, 2010.

25. Rafferty, Anthony. "Ethnic penalties in graduate level over-education, unemployment and wages: Evidence from Britain." Work, Employment and Society 26 (2012): 987-1006. [CrossRef]

26. Ram, Monder, Kassa Woldesenbet, and Trevor Jones. "Raising the 'table stakes'? Ethnic minority business and supply chain relationships." Work, Employment and Society 25 (2011): 309-26. [CrossRef]

27. Modood, Tariq, and Nabil Khattab. "Explaining ethnic differences: Can ethnic minority strategies reduce the effects of ethnic penalties?" Sociology 50 (2016): 231-46. [CrossRef]

28. Miller, Maria. Employment Opportunities for Muslims in the UK. Report of The Parliamentary Women's and Equalities Committee. London: House of Commons, 2016.

29. TUC. "Black and Ethnic Minority Women Disadvantaged." Trades Union Council Report, Trades Union Council, London, UK, August 2016.

30. Bourne, Jenny. The Race Relations Act 1965: Blessing or a Curse? London: Institute of Race Relations, 2015.

31. Bradley, Harriet, and Geraldine Healy. Ethnicity and Gender at Work: Inequalities, Careers and Employment Relations. Basingstoke: Palgrave Macmillan, 2008.

32. OITFET. Annual Report for 2013. London: Office of the Industrial and Fair Employment Tribunals, 2014.

33. Moss, Rob. "Employment Tribunal statistics released." Personnel Today, 10 September 2015.

34. EHRC. Is Britain Fairer? London: Equality and Human Rights Commission, 2015.

35. JRF. Poverty and Ethnicity: Research and Quantitative Reports by Finney, Cartney, Brynin, Nandi and Green. York: Joseph Rowntree Foundation, 2015.

36. Quillian, Lincoln. "New approach to understanding racial prejudice and discrimination." Annual Review of Sociology 32 (2008): 299-328. [CrossRef]

37. Pring, John. “Government set to slash equality watchdog's budget...again." Disability News Service, 19 April 2014. Available online: http:/ / www.disabilitynewsservice.com/government-set-to-slash-equalitywatchdogs-budget-again/ (accessed on 8 August 2016).

38. Fekete, Liz. Integration, Islamophobia and Civil Rights in Europe. London: Institute of Race Relations, 2008.

39. Fekete, Liz. A Suitable Enemy: Racism, Migration and Islamophobia in Europe. London: Pluto Press, 2009.

40. EHRC. Annual Report. London: Equality and Human Rights Commission, 2016.

41. Bagley, Christopher. The Dutch Plural Society: A Comparative Study of Race Relations. London: Oxford University Press, 1973.

42. Kremer, Monique. The Netherlands: From National Identity to Plural Identifications. Washington: Migration Policy Institute, 2013.

43. Bagley, Christopher, Nader Al-Refai, Alice Sawyerr, and Mahmoud Abubaker. "Religious and ethnic integration in British and Dutch cultures: Historical and contemporary review of citizenship, education and prejudice." Journal for Multicultural Education, 2017, forthcoming.

44. Van der Valk, Ineke. Dutch Islamophobia and Discrimination. Amsterdam: Institute for Migration and Ethnic Studies, University of Amsterdam, 2015.

45. Bovenkerk, Frank, Mitzi J. I. Gras, Dhurender Ramsoedh, M. Dankoor, and A. Havelaar. Discrimination against Migrant Workers and Ethnic Minorities in Access to Employment: The Netherlands. Geneva: International Labor Office, 1995. 
46. Andriessen, Iris, and Jaco Dagevos. "Unknown or unmeasured? On the meaning of discrimination as a factor in unemployment among Non-Western immigrants." People and Society 83 (2008): 279-301.

47. Andriessen, Iris, Eline Nievers, Laila Faulk, and Jaco Dagevos. Rather than Mark, Mohammed? Research into Labour Market Discrimination against Non-Western Migrants through Situation Tests. The Hague: Social and Cultural Planning Office, 2010 (original document in Dutch).

48. Andriessen, Iris, Eline Nievers, Jaco Dagevos, and Laila Faulk. "Ethnic discrimination in the Dutch labor market: Its relationship with job characteristics and multiple group membership." Work and Occupations 39 (2012): 237-69. [CrossRef]

49. Andriessen, Iris, D. van Den Ernst, M. van Den Linden, and G. Dekker. Foreign Origin. The Hague: Social and Cultural Planning Office, 2015 (original document in the Dutch).

50. Nievers, Eline, and Iris Andriesson. Discrimination Monitor: Non-Western Immigrants in the Labour Market in 2010. The Hague: Social and Cultural Planning Office, 2010 (original document in Dutch).

51. Engels, Friedrich. The Condition of the Working Class in England. London: Penguin Classics, 1987.

52. Bunglawara, Zamila. Valuing Family, Valuing Work-British Muslims, Women and the Labour Market. London: The Young Foundation, 2008.

53. Bracke, Sarah. "Transformations of the secular and the 'Muslim question'. Revisiting the historical coincidence of depillarization of Islam in The Netherlands." Journal of Muslims in Europe 2 (2013): 208-26. [CrossRef]

54. Abubaker, Mahmoud, and Christopher Bagley. "Work-Life Balance and the needs of female employees in the telecommunications industry in a developing country: A critical realist approach to issues in industrial and organisational psychology." Comprehensive Psychology 5 (2016): 1-12. [CrossRef]

55. Abubaker, Mahmoud, and Christopher Bagley. "Work-Life Benefits: Managers' views on implementation in Jordanian telecommunication companies." Eurasian Journal of Business and Management 4 (2016): 13-28. [CrossRef]

56. Carter, Bob. Realism and Racism: Concepts of Race in Sociological Research. London: Routledge, 2000.

57. Bagley, Christopher, Alice Sawyerr, and Mahmoud Abubaker. "Dialectic Critical Realism: Grounded values and reflexivity in social science research." Advances in Applied Sociology 6 (2016): 400-19. [CrossRef]

58. Standing, Guy. The Precariat: The New Dangerous Class. London: Bloomsbury, 2014.

59. Unwin, Julia. "Reading the riots." The Guardian Online, 8 September 2011. Available online: https: / / www.theguardian.com/uk/series/reading-the-riots?page=5 (accessed on 8 July 2016).

60. Al-Refai, Nader, and Christopher Bagley. Citizenship Education: The British Muslim Perspective. Rotterdam: Sense Educational Publishers, 2008.

61. Wilkinson, Matthew L. N. A Fresh Look at Islam in a Multi-Faith World: A Philosophy for Success through Education. London: Routledge, 2015.

62. Bagley, Christopher. “Becoming a 'non-violent extremist'." The Friend: The Quaker Journal, 17 March 2016, p. 14.

63. Ramadan, Tariq. The Quest for Meaning: Developing a Philosophy of Pluralism. London: Pelican Books, 2012.

64. Van Sandwijk, Annemarie. "The rise and fall of Tariq Ramadan in The Netherlands: The interplay of Dutch politics, media and academia." Journal of Muslims in Europe 3 (2014): 181-208. [CrossRef]

(C) 2017 by the authors; licensee MDPI, Basel, Switzerland. This article is an open access article distributed under the terms and conditions of the Creative Commons Attribution (CC BY) license (http:/ / creativecommons.org/licenses/by/4.0/). 